\title{
ESTADO LIVRE DO COUNANI: UMA QUESTÃO DIPLOMÁTICA ENTRE ESPANHA E BRASIL NO INICIO DO SÉCULO XX
}

\author{
Sandra Maria Lubisco Brancato *
}

A história do Estado Livre do Counani chama especial atenção devido às circunstân cias curiosas que envolveram a sua criação e organização.

A ação dos responsáveis pela aventura que foi o Counani chegou a preocupar seriamente o governo brasileiro, que logo tratou de se mobilizar contra eles.

O Estado Livre do Counani é escassamente conhecido, por isso é importante que, inicialmente, se coloque alguns dados relativos ao mesmo para só então examinar a questão diplomática surgida entre Espanha e Brasil em decorrência da organização do referido Estado.

O território supostamente pertencente ao Counani localiza-se ao nor te do Brasil, mais precisamente numa extensa região compreendida entre os rios Araguari e Oiapoque, que corresponde atualmente ao Território do Amapá.

A posse desta região foi durante muito tempo motivo de discórdia entre a França e o Brasil, até que, sendo a questão encaminhada ao arbitramento do Conselho Federal Suíço, foi dado ganho de causa ao Brasil, por sentença proferida em 1 ? de dezembro de 1900.

Assim, desde o início do século atual, definiu-se a fronteira entre o Brasil e a Guiana Francesa, ficando oficialmente brasileiro o referido Território. Contudo, um grupo de aventureiros chefiados por Adolfo Brezet pretendeu estabelecer ali um Estado independente a que chamaram justamente Esta do Livre do Counani.

Não era a primeira vez que a região do Amapá despertava a atenção de grupos aventureiros. Corria desde há muito a notícia de que havia ali grandes jazidas de ouro, e isto foi o suficiente para atrair grande número de pessoas. Em 1885 um grupo de franceses que circulava pela região fronteiriça entre as Guianas e o Brasil, liderado por um tal Jules Gros, já havia tentado, sem êxito, criar um Estado independente, chamado pomposamente de "République de la Guyane Independente". Esta "République" foi conhecida tam- 
bém por "República de Counani", nome este tomado de um rio que corta a região. Havia também uma pequena povoação denominada Counani.

A tentativa de Adolfo Brezet de criar o Estado Livre do Counani relaciona-se muito de perto com a aventura de Jules Grơs, não só por ter retomado o nome Counani para o Estado que pretendeu fundar. Também a inscrição "Liberté et Justice" que aparecia no escudo da "République de la Guyane Independente" foi mantida no Counani. Além disto, no "passado histórico" montado para a República de Brezet, Jules Gros é apresentado como um dos presidentes, justamente o que mais se empenhara para que a mesma fosse reconhecida por outros Estados.

\title{
PRIMEIRAS NOTÍCIAS NA ESPANHA SOBRE O ESTADO LIVRE DO COUNANI
}

Foi durante os primeiros meses de 1905 que se propagou na Espanha, com mais insistência, o tema do Counani, por ter sido neste período que surgiu a questão diplomática entre Espanha e Brasil, motivada pela organização daquele Estado. No entanto, já em maio de 1904, os leitores do jornal Unión Ibero-Americana, que se publicava em Madri, puderam ler uma matéria em que se divulgava as que foram, muito provavelmente, as primeiras notícias a circular na Espanha sobre o Estado Livre do Counani. Assina esta matéria Segundo Sarrión y Díaz Herrera, que se apresentava como representante daquele Estado em Portugal, Espanha e Marrocos. ${ }^{1}$ Os editores da Unión Ibero-Americana, certamente avaliando o impacto que causaria a matéria de Segundo Sarrión, trataram de aclarar, com muita objetividade, que não se responsabilizavam pelo conteúdo da mesma, escrevendo então a nota:

\begin{abstract}
"Hemos recibido la seguiente carta y artículo que publicamos, inspirados en la mas estricta imparcialidad, guia constante de todos nuestros actos, informando con estos documentos á nuestros lectores de algo poco conocido hasta el día, sin prejuicio de que oportunamente la Unión Ibero-Americana estudie el asunto de que se trata y emita el juicio que tan solícita y atentamente se nos pide."
\end{abstract}

Sarrión inicia seu artigo localizando geograficamente o Counani. Esclarece que a área que ocupava vinha sendo apontada pelos geógrafos como "territorios discutidos". Frisa, no entanto, que no Counani "vive y late un espíritu de independencia que, sobreponiéndose á todos los convencionalismos cancillerescos, ha hecho surgir una nación robusta y fuerte." Acrescenta ainda que o lema que aparece no escudo da República - "Por la razón ó por la fuerza" - atesta bem a combatividade dos counainenses. 
É fácil observar as imprecisões e incoerências que aparecem já neste início do trabalho de Sarrión. Em 1 o de maio de 1904, data em que é publicado na Unión Ibero-Americana, fazia mais de três anos que o Conselho Arbitral Suíço havia decidido que o Amapá pertencia ao Brasil. Portanto, em 1904, geógrafos bem informados não mais poderiam referir-se ao mesmo como sendo território discutido.

Mas a imaginação de Sarrión era prodigiosa. Counani, segundo ele, tinha uma história que remontava ao ano de 1874 , quando foi proclamada sua independência por Próspero Chaton, verdadeiro herói que "simboliza en el Counani lo que Bolivar y Washington en Venezuela y en America del Norte." Chaton posteriormente foi Presidente do Counani, sendo sucedido no cargo por Paul Cartier. A lista de presidentes do Counani é completada com os nomes de Albert Franken e de Adolfo Brezet, que recebera a presidência daquele em 1892.

Completando a "história" do Counani, Sarrión faz referência a um outro personagem chamado Cabral que teria usurpado o poder de Brezet que só voltou à presidência em 1895 por força de um movimento revolucionário. Cabral - que na fantasia de Sarrión aparece como ditador - efetivamente atuou na região, mas em circunstâncias bem distintas das descritas por Sarrión.

Conhecido como "Cabralzinho" seu nome completo é Francisco Xavier da Veiga Cabral. Em 1895, quando França e Brasil ainda disputavam o território do Amapá, comandou um movimento de resistência brasileiro ante ao avanço das tropas francesas. Integrou também um triunvirato que governou o Território do Amapá por algum tempo. Este triunvirato chegou ao poder depois que Eugene Voissien - que impunha sua autoridade em grande parte do Amapá - foi afastado, em 12 de dezembro de 1894, por força de um levantamento popular. ${ }^{2}$ Os fatos reais desmentem as afirmações de Sarrión.

Os dados publicados por Sarrión revelam nitidamente sua preocupação em dar uma consistência mais efetiva ao Estado do Counani. Além da relação de presidentes inclui em seu relato informações sobre a organização do Estado, atribuída fundamentalmente a Brezet.

A sofisticação da organização administrativa do Estado demonstra, pelo menos, que os idealizadores do Counani tinham um plano elaborado $\mathrm{e}$ grande criatividade, como fica evidenciado na exposição de Sarrión na Unión Ibero-Americana:

"El poder ejecutivo se ejerce por un jefe de Gobierno y un Consejo de Estado, compuesto de diez miembros y un Canciller, que es el segundo magistrado de la administración. Tiene una Alta Cámara, 
compuesta por tantos individuos como cantones, y un Gran Consejo, Asamblea consultiva, compuesta de igual número de miembros que la anterior. El territorio se divide en provincias y cantones; cada provincia esta gobernada por un Prefecto, asistido de un Consejo provincial de diez miembros elegidos por el pueblo; cada cantón esta gobernado por um Sub-prefecto y un Consejo cantonal, compuesto de cinco miembros, también designados por elección. La seguridad pública esta garantizada por un cuerpo permanente de policia y de gendarmes."

A esta descrição detalhảa da organização administra tiva do Counani, segue a relação completa dos integrantes de seu governo, constituído pelo Presidente e pelos Ministros das seguin tes pastas: "Interior, Negocios Extranjeros, Hacienda, Justicia y Cultos, Defensa Nacional, Agricultura, Comercio y Industria, Trabajos Públicos, Instrucción Pública, Correos y Comunicaciones." Consta também a lista nominal dos representantes do Counani em França, Inglaterra, Bélgica, Áustria, Suíça, Baviera, Espanha, Portugal e Marrocos. Aparecem ainda informações sobre a organização judiciária, ingressos do Estado, serviço militar e instrução pública, nos seguintes termos:

"La organización judicial comprende tribunales cantonales, provinciales y un Tribunal Supremo. Los ingresos del Estado provienen de los impuestos, de los derechos de Aduanas y del producto de los monopólioș. Todos los servicios de Hacienda están asegurados por la Tesorería. El servicio militar es obligatorio para todos los ciudadanos. El ejército permanente esta compuesto de voluntarios. La instrucción pública se esta organizando, y en breve se darán en el Estado todas las enseñanzas."

Não menos fantásticas que as informações anteriores são as que seguem:

"La Santa Sede nombro delegado apostólico (obispo de Counani), con jurisdicón sobre todo o pais, y es muy probable que, dadas las necessidades de la Iglesia counaniense, sea preciso crea un nuevo episcopado."

Depois de procurar acreditar o Counani junto aos leitores da Unión Ibero-Americana, Sarrión, concluindo seu artigo, chega a um tema que interessa ressaltar aqui: estimula a criação de Companhias Exploradoras no Counani, enfatizando que estas encontrariam "inmensas riquezas". Acrescenta ainda que os emigrantes que se dispuzessem a seguir para o Counani seriam ajudados e orientados pelo governo deste Estado. 
Tal propaganda tão ativa e atraente acompanhada de informações sobre um Estado que se apresentava como solidamente organizado poderia envolver a muitos. A possibilidade de obter riqueza fácil por certo seria tentadora. O Governo espanhol não ficaria impassível frente a tais acontecimentos que provavelmente afe tariam seus compatriotas.

Por outro lado, tendo presente que a questão entre Brasil e França referente a posse do Amapá fora resolvida legalmente em 1900, é compreensível que as autoridades brasileiras protestassem contra a forma como Sarrión arregimentava pessoal para ocupar aquela área. Além disto, o próprio governo francês não se interessaria em ter concentrado na fronteira com a Guiana um contingente humano que por suas características aventureiras fosse capaz de criar problemas. Contudo o primeiro desmentido público da propaganda feita por Sarrión que apareceu na Espanha não é oficial, nem do governo francês, nem do brasileiro, nem do espanhol. Foi através de uma carta, datada de 18 de julho de 1904, que um jornalista brasileiro radicado em Paris, chamado Nestor Víctor, desmentiu muitas das afirmações do representante do Counani. ${ }^{3}$

Víctor afirma inicialmente que Brezet e seus associados não eram conhecidos no Amapá. Esclarece também que esta região era habitada por selvagens nómades que dificilmente poderiam ter consciência de um "espíritu de independencia".

No que se refere aos antecessores de Brezet no governo do Counani (Paul Cartier, Jules Gros e Alberto Franken) fica claro na carta de Víctor que estes indivíduos eram aventureiros, que - como o próprio Brezet haviam sonhado em conseguir ter uma influência na região que crescia em importância graças à produção aurífera.

É sabido que durante todo o período em que o Amapá foi disputado pelo governo francês e brasileiro surgiram ali inúmeros conflitos entre garimpeiros. Não havia lei para a maioria deles. $\mathrm{O}$ que importava era enriquecer e para isto as oportunidades eram boas. Segundo informe do Boletim n? 8 do Serviço Geológico e Mineralógico do Ministério de Agricultura de 1924, em 1896 a produção de ouro na região em questão ascendeu a 1.326.264 gramas, o que representava $4 \%$ da produção mundial. ${ }^{4}$

Finalmente aparece na carta de Víctor a transcrição de um of ício do Ministério de Negócios Estrangeiros da França ao Ministério da Justiça do mesmo país, em que se lê:

"El Gobierno brasileño ha participado varias veces á este Ministerio las maniobras de un Sr. Brezet, residente en Paris, calle Legendre, n? 48, que se titula jefe del Estado independiente de Cunani (antiguo territorio contestado franco-brasileño). Despues de haber in- 
tentado contratar en Paris, bajo la capa de una sociedade titulada "Comptoirs Generaux", operarios sin trabajo dispuestos á embarcarse para el Brasil, el Sr. Brezet se esfuerza actualmente en constituir un Sindicato con el capital nominal de dos millones y quinientos mil francos, de los cuales, quinientos mil serán efectivamente pagados en especies, y trescientos mil puestos por los suscriptores á disposición del pretendido "Gobierno Cunaniano".

Según podrá usted ver por el proyecto de estatutos, esa asociación, regida por leyes imaginarias, tenía por objeto utilizar una carta de privilegio otorga da por un Estado ficticio.

Se ha realizado en Paris el día 18 de junio, en la calle Montyon, num. 15, una asemblea general, en el domicilio del Sr. Dr. Saiz, presidida por el Sr. Synave, antiguo director de una agencia de la Sociedad General.

El Gobierno brasileño ya hizo observar al Gobierno de la República que las maniobras del Sr. Brezet tienden abiertamente a preparar en Francia una rebelión en territorio cuya soberania ha sido incontestablemente referida al Brasil.

Nuestro Ministerio podrá apreciar, además de eso, si la formación de un Sindicato financiero, en las condiciones indicadas por los documentos adjuntos, no constituye un delito en los términos de la Ley francesa.

Muy agradecido le quedaré si me quiere dar su opinión acerca del modo de proceder del Sr. Brezet, sobre lo que he creído deber informar al Presidente del Consejo, Ministro del Interior, por conducto de la Seguridad General. - Decassé." 5

Como se pode observar pelo documento a "questão Counani" tinha contornos mais amplos. Também na França agiam os ardilosos aventureiros, coordenados aí diretamente por Brezet. Os pedidos do governo brasileiro para que os cunanienses fossem contidos na França tiveram boa acolhida, tanto que terminaram sendo expulsos deste país. Em 1905 o govemo do Counani já estava instalado em Londres, onde também enfrentaria sérios problemas. $^{6}$

\section{AÇÃO DOS REPRESENTANTES DO ESTADO LIVRE DO COUNANI NA ESPANHA}

No início de 1905 os representantes do Counani encontravam-se bastante bem organizados na Espanha. As fontes que utilizaremos para conhecer sua ação e os efeitos da mesma são parte da correspondência diplomática mantida entre a Espanha e o Brasil em 1905, notícias de jornais espanhóis e o livro Recuerdos de un revolucionário, escrito pelo Capitão Carlos Casero, ${ }^{7}$ que se envolveu diretamente na trama do Counani. O relato de Casero é 
bastante comprometido no que se refere à sua partícipação nos negócios do Counani. Devemos ter presente que o Capitão foi processado pela justiça espanhola por seu envolvimenito com os representantes do Counani. De qualquer forma seu depoimento é de fundamental importância porque revela situações muito específicas dos planos daqueles.

A primeira vez que o representante brasileiro em Madri - Araújo Beltrão - entrou em contacto com as autoridades espanholas para tratar da questão do Counani foi em 9 de janeiro de $1905 .^{8}$ Nesta oportunidade já tinha conhecimento da publicidade feita na Espanha sobre o Counani, fato este que não poderia mais passar desapercebido, uma vez que neste início de ano intensificava-se a ação dos counanienses, e a imprensa espanhola divulgava com insistência notícias sobre seus atos políticos. No mesmo ofício de Beltrão, citado anteriormente, consta uma transcrição do jornal de Málaga, La Unión Mercantil, de 19 de janeiro de 1905, que atesta a intensa atividade dos counanienses.

\footnotetext{
"Nuestro director D. Antonio Fernandez y Garcia, ha sido nombrado Viceconsul de primera clase, que és la denominación que figura en la plantilla consular como correspondiente a esta plaza, de Estado Libre de Counani, con la promesa oficial de ser ascendido a Consul encuanto sea reconocido por España el Estado Libre."
}

Em novo informe ao Ministro de Estado espanhol ${ }^{9}$ Beltrão, documentando mais uma vez a ação ilegal dos counanienses, em particular de Sarrión, chama atenção para notícias divulgadas por outro jornal - La Patria - de Jean de 4 de janeiro de 1905. Nesta publicação, segundo relato do Ministro, há referências sobre uma chamada Compañia Mercantil y Industrial del Counani que estava sendo organizada por Sarrión que dizia contar a mesma com respeitável capital e numerosas adesões.

O Ministro brasileiro demonstrava seu desagrado não só pela afronta de tal atitude, mas também pelo fato de que capitalistas espanhóis de boa fé estivessem sendo iludidos. Para melhor argumentar quanto ao perigo que representava deixar Sarrión agir livremente, Beltrão anexou a seu ofício cópias dos artigos que a Unión Ibero-Americana havia publicado em 1 ? de maio e 31 de outubro de 1904 e que aqui já foram referidos. Termina por pedir formalmente ao governo espanhol "providencias que dignarem-se tomar a semelhante respeito." A correspondência entre Beltrão e o Ministro de Estado espanhol seguirá por algum tempo, e cada vez com mais intensidade, insistindo sobre este particular. 
Brezet, Sarrión e seus associados alastravam perigosamente sua rede de ação. Da nomeação de representantes diplomáticos e da organização de Companhias Exploradoras, partiam para uma estratégia mais agressiva: organizar e armar dentro da Espanha um exército que, marchando para o Counani, fosse capaz de garantir sua existência.

$\mathrm{Na}$ medida em que aumentava a atividade dos counanienses, os jornais madrilenos, mais particularmente, passaram a dedicar várias colunas ao Counani. Também em muitas províncias espanholas o assunto era notícia. A repressão solicitada pelo governo brasileiro se justificava. Assustava a possibilidade de que efetivamente tivesse êxito a organização de tropas na Espanha e que estas chegassem até ao Brasil. A propaganda enganosa, as promessas falsas poderiam - sem dúvida - iludir a muitos. O Brasil já recebera denúncias concretas de que Carlos Casero ${ }^{10}$ arregimentava pessoal na Espanha e França em nome do governo do Counani, com o fim de formar o tal exército. Aranguren, representante espanhol no Brasil, informava à Madri, em abril de 1905, sobre as preocupações do governo brasileiro:

\footnotetext{
"El Señor Ministro de Relaciones Exteriores, me rogó confidencialmente comunicarse a V.E. las denuncias que acaban de formularle, relativa al titulado coronel español Casero, y aunque le manifesté que dicho sujeto, no pertenecia al ejército español, y se trataba sin duda de un revolucionario, muy conocido, insistió con empeño, para que le facilitase cuantos antecedentes conociese respecto a él, y en su vis ta dirigi à V.E. el telegrama cuya copia incluyo." 11
}

Aranguren, complementan do sua nota, manifesta o temor de que a mobilização de Casero podia também resultar nefasta para a Espanha, "porque podrá muy bien resultar que valiendose de este pretesto tratese de soliviantar los animos en España con fines que nos tocassem mas de cerca y con trabajos y promesas ficticias." A recor dação do passado revolucionário de Casero certamente pesaria nas resoluçoes que pudesse tomar o governo espanhol. Seguem no mesmo tex to algumas informações sobre Brezet e sua atuação em outros países:

"...titulandose Presidente del Estado Libre de Cunany [Brezet] ya se ha dirigido en varias ocasiones, à casi todos los Estados de Europa, pretendiendo ser reconocido como Jefe del tal Estado libre, pero apesar de su fracasso, hace creer que tiene representantes acreditados en diferentes partes incluso en España. Reside ahora en Londres habiendo huido de Paris, su antigua residencia, perseguido por la policia francesa." 
Interessa também salientar a informação de Aranguren de que no território que Brezet tentava fazer passar como Estado independente não havia nenhum agente ou representante seu. Esta informação contrasta vivamente com os dados sobre a organização do Estado de Counani divulgados por Sarrión na Unión Ibero-Americana de 1 ọ de maio de 1904, já anteriormente referidos.

Tomava vulto a questão Counani, ao mesmo tempo em que se intensificava a pressão do governo brasileiro sobre o espanhol, para que fosse punida a ação ilegal dos representantes do Counani na Espanha.

\section{REPRESSÃO ESPANHOLA AOS CONTRAVENTORES DO COUNANI}

Apesar dos apelos formais feitos pelo Brasil no início de $1905^{12}$ para que o governo espanhol tratasse de conter Sarrión, Casero e seus companheiros, ainda em maio deste mesmo ano o assunto não fora resolvido.

Por esta razão no dia 4 do citado mês, Araújo Beltrão volta a insistir com mais veemência para que, em definitivo, os counanienses fossem contidos. Em ofício enviado ao Ministério de Estado chega a fazer uma acusação direta à polícia espanhola que, segundo ele, estaria agindo com "tolerancia inaudita" para com os que chama de "filibusteiros". A estes comentários acrescentava com dureza:

\footnotetext{
"...rogo-the pela terceira vez e ao seu Governo, que digne-se de providenciar devidamente, afim de que pelas auctoridades competentes, não continuem a deixar de ser feitos, com a urgencia e precauções rigorosamente necessárias, as diligências que me parecem cumprirlhes, tanto para salvaguardarem os interesses e as vidas dos seus seduzidos compatriotas, como para impedirem, finalmente, que, em sua presença e apesar dos meus anteriores avisos, continue essa cafila de salteadores a conspirar em público, contra a integridade do território de um paiz amigo, como é, sem dúvida alguma, o Brazil de Hespanha."
}

Fica nas palavras de Beltrão um apelo suficientemente claro à amizade Brasil/Espanha e uma velada advertência de que esta não deveria ser abalada por uma omissão do governo espanhol. Para melhor fundamentar a necessidade de uma pronta ação das autoridades espanholas, desta vez o Ministro transmitia informações mais concretas sobre os planos dos counanienses, conseguidas graças a infiltração de pessoas de sua confiança nas reuniões realizadas por Sarrión. ${ }^{13}$ Estas informações não eram nada tranquiilizadoras. 
Sarrión já teria conseguido organizar uma expedição de quatro mil homens, sob o comando de Casero, e com cerca de duzentos e cinqüenta oficiais; as nove brigadas que formavam o curioso exército embarcariam rumo ao Brasil sucessivamente em portos franceses e espanhóis, a partir do mês de maio de 1905. Em concreto o plano dos "beligerantes" era de entrar no Brasil primeiramente como imigrantes, para só depois se reunirem para defender a independência do Counani.

Contudo, o Ministro brasileiro necessitava de provas ainda mais definitivas contra os counanienses, para reforçar seus pedidos de que fossem aplicadas medidas punitivas severas contra eles. É o que se depreende da leitura da parte final do of ício que vimos citando:

\footnotetext{
"Era-me excusado accrescentar que nessas diligencias, deverão ser apprehendidos, pelos agentes de máxima confiança do Exmo. Snr. Governador Civil ou da superior Auctoridade policial de Madrid, todos os documentos existentes no indicado piso da casa n? 16 na rua do Marqués de Santa Ana, afim de serem entregues ao Tribunal competente, como dispõem as leis deste Reino, juntamente com Scgundo Sarrión y Diaz de Herrera e os demais chefes da conspiração que acabo de denunciar."
}

Finalmente na madrugada do dia 5 de maio são tomadas as providências que tão insistentemente eram reclamadas pelas autoridades brasileiras: a polícia da capital espanhola faz uma batida na residência de Sarrión, dá ordem de prisão ao mesmo e apreende uma série de documentos encontrados no local.

Estas ocorrências tão extraordinárias não tardaram a ganhar as manchetes dos principais jornais madrilenos. O Heraldo de Madrid foi o que mais se deteve sobre o assunto, entrevistando várias pessoas envolvidas no caso que agora vinha a público com toda a força. ${ }^{14}$

Uma constante no depoimento dos envolvidos no caso foi a preocupação de inocentar-se. O Heraldo de Madrid revela que todos afirmaram que os trabalhos preparatórios da expedição para o Brasil tinham sido feitos com toda a publicidade, sendo tratado o tema inclusive com Centros Oficiais e Ministérios espanhóis. Completando esta argumentação teriam acrescentado ainda: "si no se dieron por enteradas [as autoridades espanholas] fué sensillamente porque no quisieron y porque les convenía, toda vez que la expedición iba á estar constituída principalmente por elementos ó individuos que las autoridades españolas verían con gran gusto salir de aquí."

Os entrevistados preocuparam-se também em chamar a atenção de que o engajamento de muitos às forças do Counani se justificava porque, na Espanha, haviam perdido seus postos, principalmente no exército, por "per- 
manecer fieles a determinados principios". Devido a isto "emigraban en busca de pan y de lo que... ahora es imposible implantar en España".

Fica claro neste depoimento a tentativa dos counanienses de sensibilizar a opinião pública ante a difícil situação que enfrentavam, segundo eles, devido principalmente aos expurgos feitos no exército. É evidente a crítica feita ao regime e governo espanhol. Este tipo de manifestação não poderia ser bem vista pelas autoridades espanholas, sempre atentas à mobilização dos republicanos, notadamente daqueles que, como Casero, já tinham atuado ativamente em prol de uma República. As providências tomadas pela polícia de Madri devem ser entendidas levando em consideração estas circunstâncias.

Ainda, valendo-se das informaçoes dos entrevistados, o Heraldo de Madrid esclarece que a missão do exército do Counani consistia em apoiar a instauração efetiva do governo republicano neste Estado, além de defender seu território de possíveis investidas "imperialistas" do Brasil. A expedição estava em fase de adiantada organização; contava com vários navios que deveriam ser encarregados de transportar o exército. $\mathrm{O}$ capital que contavam para financiar tão ousada empresa seria facilitado por um Comitê que funcionava em Londres, junto às principais autoridades do Counani.

El Liberal, um dos mais antigos e prestigiados jornais da capital espanhola, também ocupou-se do Counani. ${ }^{15}$ Nas declarações de Sarrión publicadas por este jornal aparece, com muita insistência, a afirmação de que a organização do Esta do Livre do Counani "tratabase de un negocio prefectamente licito y admisible", o que, efetivamente, não correspondia a verdade. Basta lembrar, mais uma vez, que desde 1900 o Conselho Arbitral Suíço havia reconhecido que a região do Counani pertencia ao Brasil.

Tão curiosa como a insistência na legalidade do Counani é a afirmação de Sarrión feita, ainda a El Liberal, de que o Comitê Geral do Estado Livre do Counani estabelecido em Londres "no trabaja em conspirar contra la República del Brasil, con la cual el Estado Libre se halla en las mejores relaciones diplomáticas." A falta de seriedade do representante do Counani fica patente nestas declarações que levam ao descrédito toda a mobilização feita até então pelas lideranças do Counani.

O Heraldo de Madrid, já no dia 8 de maio, uma vez avaliadas as primeiras declaraç̃es de Sarrión, publicadas no dia anterior, não hesitou em afirmar:

"...la cuestión de Counani es una moderna empresa que, por sus circunstancias, recuerda las antiguas conquistas y ocupaciones de territorios inexplorados, confiadas a aventureiros intrépidos y audaces."16 
Muito sugestiva é também a forma como o Heraldo de Madrid subtitula o último item desta coluna no dia oito de maio: "colorin colorao...", maneira como tradicionalmente na Espanha termina a narração dos contos de aventuras infantis. $O$ jornal não dava mesmo crédito às fantásticas declaraçōes feitas por Sarrión na "Carcel Modelo", onde já se encontrava detido. ${ }^{17}$

Assim é com indisfarçável ironia que publica os dados facilitados por Sarrión relativos à sua nomeação para Ministro Plenipotenciário do Counani e à vinculação de membros da familia real inglesa com os negócios daquele Estado. Inclui ain da detalhes referentes à organização do exército e aos trâmites feitos em diversos países europeus para ultimar o reconhecimento da República do Counani.

Algumas informações fornecidas por Sarrión ao Heraldo de Madrid sobre as finanças do Counani evidenciam, mais uma vez, sua desonestidade, como se pode observar:

"...en Paris se habia formado primeramente un Sindicato, el Comptoir Francaise, que rompió con el Presidente de la República do Counani, Sr. Brezet, formandose entonces el Sindicato inglés, en el cual han ingresado, uno de los Bancos más ricos, muchos financieros y miembros de la familia Real y de la aristocracia.

Se emitirán un préstamo de 100 millones de libras esterlinas, divididos en dos de 50, de los cuales se han lanzado ya á los mercados bursátiles papel por valor de 400.000 libras, que se cotizan extra oficiaimente.con 40 por 100 de prima em las Bolsas de Paris y Londres.

Los ingresos de la Hacienda de la República de Counani. los constituyen la recaudación de Aduanas y un impuesto sobre la capitación. En instantes criticos se han emitido por veces bonos que ascienden á la suma de 500.000 francos y han sido aceptados."

Recorde-se que Brezet e seus companheiros tinham sido expulsos de Paris pelas autoridades francesas. Assim Sarrión omitia detalhes da atuação de seu Presidente na Capital francesa que possivelmente teriam alguma vinculação com o rompimento entre ele e o Comptoir Francaise, se é que este sindicato realmente existiu.

Para avaliar as afirmações de Sarrión sobre o capital que dispunha o Counani, é importante que se tenha presente os comentários feitos pelo jornalista Nestor Victor na Unión Ibero-Americana, já citado anteriormente, bem como a correspondência oficial do Brasil para Madri que vimos examinando. Através destes textos fica provado que no Amapá não se tinha conhecimento da presidência de Brezet. Como poderia então haver ingressos na Fazenda do Counani? 
Casero em seu livro de memórias, Recuerdos de un revolucionario, narra a verdadeira situação financeira do Counani e de seus dirigentes, conforme se verá. As revelações de Casero, de um modo geral, são bastante comprometidas, uma vez que, tendo sido processado devido a seu envolvimento com o Counani, é lógico que quisesse reafirmar sua inocência, mesmo depois de passados os acontecimentos.

Contudo, as informações que fornece, excetuando aquelas relativas a seu envolvimento pessoal com o Counani, são bastante válidas, não só para identificar os principais elementos envolvidos no caso, como também para conhecer seus planos e estratégia de ação.

\section{AS REVELAÇÕES DE CARLOS CASERO}

O contacto direto de Casero com os dirigentes do Counani ocorreu em Londres, quando o revolucionário espanhol, por consenso do grupo envolvido no caso em Madri, se deslocou para aquela capital, com o fim de apurar a ver da deira situação dos negócios do Counani.

A primeira suspeita séria do grupo madrileno de que algo de errado havia com o Counani surgiu quando chegou a notícia de que Brezet e outros in divíduos envolvidos com o Counani haviam sido expulsos de Paris. Pedidos os esclarecimentos, a resposta que receberam de Lapuya - jornalista espanhol que se intitulava Secretário dos Negócios Extrangeiros do Counani foi de que ocorrera "una mala interpretación de aquel Gobierno [francês], creído que se trataba de una estafa"18 [a açã̃o dos counanienses], acrescentando ainda que, "una vez aclarado el asunto, no volverían á ser molestados." 18

Não satisfeito com esta resposta, o grupo madrileno financiou a ida de Casero a Londres, onde desembarcou em 19 de abril de 1905, hospedando-se no mesmo local onde já se encontravam Lapuya, Brezet e uma mulher que vivia em sua companhia.

No dia seguinte à sua chega da Casero foi levado pelo presidente Brezet à sede do Counani, instalada em uns escritórios, em cujas portas se podia ler a inscrição "Camprell Everden y Compañia". Abaixo desta aparecia o nome do Counani junto a de outros locais situados nas Antilhas. Trabalhavam no escritório mais ou menos vinte empregados, distribuídos pelas diversas sessões. ${ }^{19}$ Se no considerado território do Counani não se tinha notícia da existência deste Estado, tudo parece indicar que, pelo menos em Londres, era real e podia ser identificado.

Casero, apesar de verificar que Counani tinha uma organização concreta percebeu logo, segundo declara, que havia irregularidades com os negó- 
cios daquele Estado. Entre o grupo dirigente, por exemplo, não havia um perfeito entendimento. 0 próprio Presidente dizia ignorar o teor da correspondência enviada por Lapuya à Espanha como querendo eximir-se de qualquer responsabilidade relativa ao mau andamento dos negócios do Counani naquele país. Este fato causou grande estranheza a Casero que desde então passou a controlar mais detidamente a mobilização da "alta cúpula" do Counani. ${ }^{20}$

Muito curiosas são as revelações de Casero relativas à situação econômida dos dirigentes do Counani. Brezet e sua companheira, apesar de receberem salários pelas funções que desempenhavam, na administração do Counani viviam com grandes dificuldades financeiras. Casero e alguns integrantes do governo terminaram sendo atingidos pelo aperto financeiro dos dirigentes do Counani, como se depreende do seguinte relato:

\begin{abstract}
“...á la hora de la comida era cuando había que ver á quel microscópico gobierno.

Cinco personas alrededor de una mesa bien provista de servilletas, cubiertos y platos, y en su centro una magnifica lata de sardinas, por cierto de la fabrica de Lugo; una gran fuente de patatas cocidas, sin sal y sin mondar, y su correspondiente hermoso vaso de agua para cada uno. ...al segundo día de repetirse la escena de las patatas cocidas, protesté de una manera tan aparatosa y ruidosa, que cada cual optó por excusarse de la mejor manera posible, si bien la actitud del excelentíssimo señor ministro plenipotenciario fué la de seguir comiéndolas, al mismo tiempo que entonaba un himno de alabanza en honor de manjar tan exquisito. El presidente se excusó diciéndonos que sentia aquel percance, pero que él no podia hacer otra cosa en nuestro obsequio; que carecia de fondos y que hacía todo lo que era posible." 21
\end{abstract}

Esta precária situação contrastava com a opulência ostentada por Everden, chefe dos escritórios que gerenciavam os negócios do Counani. Outro curioso relato de Casero evidencia esta situação:

"Uno de aquellos días, M. Everden y Compañía tuvo la feliz idea de obsequiarnos á comer en su casa, y allí nos fuimos todos aquella misma tarde llenos de gozo, siquiera fuera en obsequio á la variación de la comida que nos esparaba.

Ya en marcha y transportados por el ferrocarril, á media hora nos encontramos en uno de los arrabales de Londres y frente á un bonito hotel, compuesto de planta baja, principal y un hemoso jardin. Sonó el timbre y abrióse la puerta en el acto. Nos salió al encuentro una servienta, la que anunció á sus señores nuestra presencia; acto seguido aparecieron Mad. y M. Everden en el recebimiento; después de los saludos y presentaciones oficiales de todo aquel cuerpo diplo- 
mático, fuimos conducidos al comedor. Alli pudimos observar que nos encontrábamos en la casa de un rico banquero; por todas partes se observaba el'lujo, la comodidad y la esplendidez." 22

Tudo parece indicar que a privilegiada posição econômica de Everden servia de respaldo para algumas das transações feitas pela causa do Counani, já que o Presidente Brezet não teria condições para circular nas altas rodas financeiras de Londres. Contudo, no planejamento dos negócios, Brezet participava diretamente tendo o cuidado de impedir que Casero pudesse obter detalhes dos mesmos. Esta situação irritava profundamente a Casero, conforme se observa na descrição que faz da situação que envolveu a compra pela Everden de alguns barcos leiloados pelo governo inglês. Para ocultar de Casero os planos relativos a este negócio foram utiliza dos alguns artifícios nada menos que cômicos que incluíam seu afastamento dos escritórios da Camprell Everden y Compañia. Para tanto foi solicitado o auxilio de "La Presidenta" ${ }^{23}$ e de madame Ruzó, esposa de um dos principais assessores de Brezet. A tarefa das mesmas consistia em reter Casero na hospedaria que ocupavam, conforme ele mesmo explica:

"...puesțas de acuerdolas dos mujeres, la presidenta y la de M. Ruzó,
pronto fui sorprendido con la presencia de esta ultima, la que co-
lándose de rondón en mi habitación, y bajo la disculpa de que
quería enseñarme todas las fotografias de su familia, se sentó en el
lecho que yo ocupava y junto á mi empezó á hacerme el relato de
la edad, estado y posición de cada una de aquellas copias.".

O plano da compra dos barcos - a dar crédito ao depoimento de Casero - revela claramente a má fé da alta cúpula do Counani:

\begin{abstract}
"Por conversasiones oídas á la señora de M. Ruzó y por lo que yo pude sonsacar, supe á ciencia cierta que los propósitos del presidente eran, una vez pagado el primer plazo por los Bancos, valerse de ellos para explotar la buena voluntad de los incautos y dar el golpe seguro á favor de los cincuenta millones tan deseados." 25
\end{abstract}

Quando Casero consegue meios para se retirar de Londres seu afastamento é festejado com indisfarçável alegria pela equipe do Counani. A descrição que Casero faz de sua retirada é extremamente pitoresca:

"...me propusieron que en aquel mismo día podría salir de Londres. No bien había vuelto la espalda puesto los pies fuera del umbral de la puerta del cuarto, cuando of el palmoteo general y el ruido que producían las muestras de júbilo y alegría que les producía mi partida. 
Como tarareando una canción y de modo que llegara hasta ellos la voz, les llamé canallas, granujas, y continué bajando la escalera hasta encontrarme fuera de aquella casa." 26

De retorno a Madri, Casero informou seus companheiros sobre suas experiências em Londres e sobre o contacto com os dirigentes do Counani, liberando, posteriormente, a todos de qualquer compromisso com a causa. Dias depois, acusado de "cunanista" 27 enfrentou um processo do qual terminou sendo absolvido.

\section{ENCERRAMENTO DO CASO COUNANI}

Ao punir Sarrión e seus companheiros em Madri, as autoridades espanholas evitaram que se criasse uma questão diplomática mais séria entre a Espanha e o Brasil.

A insistência com que o representante brasileiro em Madri pressionava para que fosse tomada providências em relação ao caso ${ }^{28}$ demonstra que $o$ governo brasileiro efetivamente estava preocupado com a mobilização dos counanienses e que não aceitaria que as autoridades espanholas continuassem omissas.

Uma vez efetuada a prisão de Sarrión, Araújo Beltrão ocupou-se em fornecer provas mais amplas que deveriam, junto à outras já obtidas, instruir o processo que corria contra o representante do Counani na Espanha. Neste sentido envia uma correspondência ao Ministro de Estado espanhol, ${ }^{29}$ onde anexa uma documentação bastante significativa. Entre ela se destaca o parecer de dois jurisconsultos espanhóis - Senador D. Eugenio Montero Ríos e o Deputado Juan Poveda García - condenando Sarrión, além de um mapa que localizava o território do Counani.

Apesar das evidências que depunham contra o grupo responsável pelo Counani, este continuou tentando dar um caráter oficial ao Estado Livre, mantendo uma correspondência oficial com o Governo espanhol. Já desde o início de 1905 chegava a Madri esta correspondência que protestava contra "la actitud tomada por el Gobierno de S.M.C. frente al libre ejercicio de la representación del Esta do Libre en España."30

Posteriormente é encaminhado por Sarrión ao Ministério de Estado español um dossier intitulado Protesta al Excmo Sr. Ministro de Estado ${ }^{31}$ que contém cinco documentos extremamente curiosos e que atestam, pelo menos, que os dirigentes do Counani tinham grande persistência na defesa da legalidade de seu Estado. 
O primeiro destes documentos, assinado por Sarrión, é um protesto formal contra a agressão sofrida por ele: a batida policial em sua casa; a apreensão de documentos no mesmo local e, principalmente, sua prisão que é entendida como "una flagrante violación de derechos individuales tan sagrados como el de seguridad personal y el de invioabilidad del domicilio." 32 Sarrión coloca no mesmo documento que também como representante diplomático do Counani tinha sofrido uma grande injustiça, pois este país "lejos de sentir ó manifestar hostilidad hacia España, solicita y desea su amistad." Sua argumentação não para aí. Acrescenta que:

\begin{abstract}
"...las naciones de Europa y gran parte de las de America y Asia han visto con penoso asombro estos sucesos realmente extraordinarios $\mathrm{y}$ como se han infringido en daño mio las leyes interiores y las reglas y practicas mas usuales y rudimentarias del Derecho de gentes. No ya tratandose de un Estado como el de Counani, que tiene en su favor el jus possidendi, la independencia de hecho y la soberania efectiva desde hace mas de treinta años, que para mantener su vantajosa situación ni siquiera necesita sostener guerra con las naciones vecinas, y cuyos funcionarios diplomáticos y consulares disfrutan de los mayores respetos y consideraciones en todas partes; si no aun tratandose de Colonias sublevadas la conducta de los Gobiernos normales con las Representaciones de los pueblos rebeldes ha sido siempre muy opuesta á la observada aqui comigo."
\end{abstract}

Como se pode observar, a argumentação de Sarrión é mentirosa, desonesta. A França - como fazia agora a Espanha - já tinha tomado medidas legais contra os envolvidos com o Counani, expulsando-os de seu território. Quanto ao "jus possidendi" e a "independencia de hecho y la soberania efectiva desde hace mas de treinta años", se sabe que são improcedentes, considerando não só o laudo arbitral suiço de 1900 , como também a situação concreta de ocupação da região.

Quanto ao relacionamento cordial mantido pelo Counani com as naçбes vizinhas, a inconsistência do argumento é ainda mais patente. Como não considerar que o governo brasileiro, alarmado com a mobilização dos counanienses, tivesse pedido providências a Espanha? Este fato, aliás, é referido pelo próprio Sarrión, no mesmo documento que vimos citando:

"Al Gobierno de S.M.C. acudo, pues, en demanda de amparo y protección y de justicia cumplida contra los que sin ella me han perseguido y maltratado, y espero de V.E. que acoja benebolamente esta reclamación, para cuya eficacia invocando las primarias prescripciones y practicas del Derecho internacional, pido a V.E. y por su conducto al Gobierno de S.M.C. de que dignamente forma parte, que tomando en cuenta la razon de mi demanda, exija del Gobierno 
Brasileño una cabal satisfación por el agravio que me ha inferido $y$ una indenización pecuniaria proporcionada y cuya cuantia puede fijar V.E. en su reconocida justificación."

O caso Counani ia aos poucos assumindo forma de uma verdadeira ópera bufa.

Desde Londres a cúpula dirigente do Estado Livre apoiava integralmente a ação diplomática de Sarrión. Consta do citado dossiê uma cópia de uma comunicação envia da por Lapuya a Sarrión, onde fica expresso o apoio integral à ação do Ministro. Há também na mesma uma indisfarçável intensão de reafirmar, novamente, o caráter legal de que queriam que se revestisse o Estado Livre. A argumentação usada mais uma vez é falha e encobre a verdade com uma terminologia apoiada em normas de direito internacional que não se aplicavam ao caso. É importante novamente ter presente que os líderes do Counani defendiam os direitos do Estado que representavam, considerando como território nacional deste uma área que reconhecidamente era brasileira.

Como a comunicação referida expressa claramente esta situação, é importante que se conheça em sua íntegra.

Comunicación del Exmo. Sr. Consejero de Estado secretario de Negocios Extrangeros del Estado Libre

Estado Libre du Counani $=$ Liberté-Justice $=$ Conseil d'Etat $=$ Affaires Etrangéres $=$ Premier bureau $=\mathrm{n}$ ? $171=\mathrm{Al}$ Exmo. Sr. D. Segundo de Sarrión y Diaz Herrera. Ministro Plenipotenciario del Estado Libre del Counani en Madrid $=$ Exmo. Sr. $=$ Tengo el honor de transmitir á V.E. las mas calurosas felicitaciones del Jefe del Estado y de este Gobierno por la dignisima actitud que V.E. ha adoptado en el desagradable incidente que hoy relata la prensa toda de Europa $=$ El Estado Libre del Counani realiza su obra de Independencia respetando las leyes de todos los paises asi en los que tiene representación diplomática, como en aquellos en los que hasta ahora no se halla representado = Es evidente que las injustas pretensiones de los Estados Unidos del Brasil a la denominación del Estado Libre del Counani experimentan grande contrariedad con nuestros trabajos, pero es esta una cuestión de orden particular entre ambos pueblos y en la que ningun otro tiene derecho de mezclarse. Al acudir el Brasil á la Potencias Extrangeras en demanda de auxilios con que contrarrestar nuestra obra, demuestra su fraqueza. Si alguna Potencia escuchar estas reclamaciones de modo complaciente, demonstraria una arbitrariedad contra derecho. Pero en ningun caso la obra de Independencia del Counani se interrumpiría un solo momento = A la sombra del pabellon del Counani, en el suelo de nuestra patria americana ó bajo el pabellon ingles que $c 0-$ noce la libertad y acata sus hospitalarios preceptos, el Jefe del Esta- 
do Libre del Counani no olvidara nunca el admirable concurso que á la Independencia estan prestando los generosos españoles por V.E. designados para nuestra obra diplomatica $=$ Sirvase transmitir V.E. esta felicitacion colectiva y aceptando la personal del Jeje del Estado y del Gobierno Counaniense, reciba V.E. también mi testimonio de alta consideración con que le saludo = Londres, en misión, 8 de mayo de 1905 = Le Coinseller d'Etat = Secretaire aux Affaire Etrangeres $=$ Lapuya [rubricado]. .

Inclui-se ainda no dossiê uma circular enviada também por Lapuya a agentes diplomáticos do Counani em diversas cidades européias. Nesta circular; além de historiar os "atropellos cometidos por las autoridades españolas" na detenção de Sarrión, volta a defender os supostos direitos do Esta do Livre. Declara ainda que no Counani sempre houve a preocupação de agir corretamente com os outros Estados.

Lapuya jogava contra as evidências. Como negar que se articulava uma conspiração contra o Brasil na casa de Sarrión? Os documentos apreendidos e a arregimentação de tropas comprovada pelas autoridades brasileiras em Madri não davam margem à dúvidas.

Quanto à alegada lisura da conduta dos dirigentes do Counani em Londres, poderíamos apenas recordar seus negócios referentes à compra de barcos para refutá-la.

Encerra o dossiê a cópia de um ofício de Sarrión ao Ministério de la Gobernación da Espanha, insistindo sobre a inocência das reuniões que realizava com seus companheiros em sua residência. Cabe lembrar aqui, mais uma vez, que foi apoiada nas provas encontradas na residência de Sarrión que a polícia madrilena pôde mantê-lo preso durante as 72 horas que a lei permitia. Por certo, para fugir a uma possível condenação, posteriormente, Sarrión escapou para Londres. Novamente a inconsistência da argumentação do representante do Counani se evidencia. ${ }^{33}$

Apesar de todos os atropelos sofridos pela causa do Counani, uma vez em Londres Sarrión não foi levado a sério pelos chefes daquele Estado. Casero em seu livro de memórias conta que "siempre que Sarrión saludaba á monsieur Everden, este le contestaba de una manera burlesca y satirica: - ¿Donde están los 4.000 hombres reclutados?"34 O descrédito na ação de Sarrión, manifestado de forma tão direta por Everden, contrasta com a postura oficial mantida pelos dirigentes do Counani em sua correspondência oficial a Madri, conforme já se viu anteriormente. Continuavam se sucedendo as contra dições no Caso Counani. Apesar de desconsiderar a Sarrión, era sobre os acontecimentos que o envolveram em Madri que se apoiava o governo do Counani para, ainda em outubro de 1905, manter uma correspondência oficial com o governo espanhol. A tônica desta correspondência era a mesma das anteriores: reclamar sobre as perseguições sofridas por seu representante 
en Madri e insistir novamente sobre o caráter legal do Counani, agora através de uma fundamentação teórica. ${ }^{35}$

A ousa dia dos chefes do Counani não tinha limites. Se pode mesmo afirmar que além de ousados pareciam ingênuos. Quem os levaria a sério depois de todo o ocorrido? Os percalços sofridos pelo representante oficial do Counani em Madri eram suficientemente conhecidos. Em 16 de agosto de 1905, o Heraldo de Madrid voltou a tratar do tema Counani, desta vez fornecendo, com muito humor, detalhes importantes sobre os seus dirigentes. Como estes detalhes elucidam bastante toda a trama, interessa reproduzir aqui os mais significativos.

"Os presento á M. Adolfhe Bréset, Presidente del Estado Libre del Counani, hombre joven, aunque averiado en su físico por señales inequívocos de haber vivido una existencia acelerada. El clima tropical ha legado á su cuerpo y cara señales indelebles. Por su aspecto parece militar. Lo fué un tiempo no lejano, perteneciendo al ejército colonial de Francia, y prestó sus servicios en la Guyana Francesa, desde donde acometió raids temerarios al país del que de llama Presidente. En su carrera militar ha sido modesto: sólo ostentó en su bocamanga los galones de cabo.

No obstante, es hombre muy inteligente; posee tres idiomas, francés, inglés y español, y es por las tazas, un tan habil financiero que va colocando bonos de cantidades diversas, bonos para la Sociedad explotadora de las riquezas de Cunani, y que vienen á convertirse en rentas con que arenderse.

El Secretario del Estado Libre de Cunani es Ruró, antiguo miembro de una banda militar francesa y tan enemigo de la música alemana, que cierto día, despues de haber asistido á una audición de Parsifal, salió tan aburrido á la calle, que, oyendo á una banda de tambores de un regimento de hulanos, abrió los ojos desmesuradamente y, dejando pasar con franqueza una sonrisa de plena satisfacción, exclamó gozoso:

- |Gracias á Dios que oigo música! i

Ruró es hombre que tiene que satisfacer necessidades, y las satisface con holgura sirviendo á Brezét. Es una de esas criaturas moldeables, que son buenas ó malas según las maneja un honrado ó un canalla.

$\mathrm{Y}$ vamos con la Presidenta. Usa el mismo nombre que la heroina del amor creada por Goethe. Margarita tiene rubias guedejas, ojos soñadores y picarescos, nariz bien pergeñada y una caja de perlas por boca, aprisionada en el marco grana de sus labios voluptuosos. $\mathrm{Su}$ arte en el vestir recuerda a la mujer del bulevar y su conversación insinuante hace reconocerla en seguida: es parisienne... Una de tantas que, rehuyendo la caŕda, pecó; más reflexiva que viciosa, buscó la enmienda. Paris, con su torbellino, no la atraia; cruzó el Canal, y en uno de aquellos periódicos de la babilónica London anunció sus servicios, pasó por la CAMPBELL EVERDEN, atisbóla Brézet, 
prendóse de su gracia sandunguera y cayó en sus brazos. Está proxima á llamarse MADAMA Brézet, pues el Presidente, que tiene en Paris esposa y dos hijos, gestiona su divorcio para casarse de nuevo.

Hay otro personaje: es el Ministro de Relaciones Exteriores del Esta do de Cunani, Hombre inteligentisimo, bueno y victima de su candorosa manera de ser. Soñador, por la República española, capaz seria de ascender á las cumbres del Himalaya si en sus picos encontrar pudiera la revolución.

Nuevo DIOGENES, enfocó su linterna hacia Cunani creyendo de buena fe que con constancia podria alguna vez transportar á Paris aquellas quiméricas riquezas, para poder decir á España, su pais: "Ahi tienes el dinero que se necessita para transformar el régimen. iViva la República!"

Este Ministro de un Estado seudoimaginario, y que ha dejado de pertenecer á la Sociedad Explotadora del Cunani por no haber podido aportar las 500 libras esterlinas que como accionista exigiera Brézet, es Lapuya, periodista residente en la capital de Francia." 36

Foi também o Heraldo de Madrid que, no final de 1905, publicou a seguinte notícia:

"...reuniénronse anoche, ["supervivientes de la jornada del 19 de septiembre, Carlos Casero y demás compañeros"'] en el Casino republicano de la calle de Pontejos, á tomar café en recordación de la página revolucionaria que ellos, con el malogrado Villacampa, escribieron en la historia contemporánea española.

Menos mal que Casero, espiritu humorista, amenizó los recuersos tristes del 19 de septiembre con notas jocosísimas sobre la supuesta República de Cunani, algunas de las cuales han visto la luz recientemente en el Heraldo..." 3 7

Se o próprio Casero, que teve um envolvimento tão direto com o Esta do Livre do Counani, já em setembro de 1905 burlava do mesmo, como as autoridades espanholas em outubro do mesmo ano poderiam levar em consideração a fundamentação legal usada pelos governantes do Counani para justificar seus direitos?

Sem dúvida, o negócio do Counani não passou de uma ardilosa trama. É evidente que por trás de elementos de menor expressão, como Brezet, Casero e Sarrión, atuava o verdadeiro dirigente da empresa - Everden - que inclusive tinha meios econômicos para agenciá-la, ao contrário dos demais.

Não foi somente na região do Amapá que o Governo brasileiro enfrentou problemas como os do Counani. Em 1899 outro aventureiro, Luis Gálvez Rodrigues de Arias, de nacionalidade espanhola, proclamara no Acre uma república independente. Apoiado por um grupo de seringueiros chegou 
a organizar o governo da nova república, tentando, inclusive, conseguir seu reconhecimento em alguns países europeus. Como no caso do Counani, a empresa não foi adiante, mas mesmo assim causou na época sérios transtornos às autoridades brasileiras.

Além do Brasil, outros pontos da América também sofreram a ação de aventureiros que tentaram criar novos Estados. Tal é o caso de Antonio de Tounens que, em 1861, conseguiu ser aclama do rei da Araucania e Patagonia, com o nome de Orelio Antonio I. A pronta ação do governo chileno frustou seus planos.

Com estes precedentes se justificava que o governo brasileiro ficasse apreensivo com a mobilização dos counanienses, exigindo então que as autoridades espanholas tratassem de contê-los. A colaboração espanhola neste sentido, depois de um primeiro momento de indiferença, impediu que tomasse vulto uma questão diplomática mais séria entre a Espanha e o Brasil.

\section{NOTAS}

${ }^{1}$ Sarrión informa sobre o Counani com tantos detalhes que deixa nitidamente a impressão de que era a primeira vez que se dava conhecimento ao público espanhol da existência do Estado Livre do Counani. A matéria publicada por Sarrión se intitula "Un Nuevo Estado Americano - La República de Counani" e encontra-se no Unión Ibero-Americana de $1^{\circ}$. de maio de 1904 (A té que indique o contrário, as citações do Unión IberoAmericana que seguem são desta edição de 1 ? de maio).

${ }^{2}$ Sobre este tema veja a obra de REIS, Arthur César Ferreira. Território do Amapáperfil histórico, Rio de Janeiro, Departamento de Imprensa Nacional, 1949, p.97 a 102.

${ }^{3}$ Cf. Unión Ibero-A mericana. "El Counani", Madrid, 31 de outubro de 1904.

${ }^{4}$ Apud. MEIRA, Sîvio Augusto de Bastos. Fronteiras Sangrentas - Heróis do Amapá. Rio de Janeiro, Edição do Autor, 1977, p.45.

${ }^{5}$ Como Nestor Víctor afirma em sua carta que o ofício do Ministério dos Negócios Estrangeiros da França foi publicado "hace pocos dias", infere-se que o referido ofício seja de julho de 1904, já que a carta de Víctor é deste mês e ano.

${ }^{6} \mathrm{Em}$ ofício de Araújo Beltrão, Representante do governo brasileiro em Madri, ao Ministro de Estado Espanhol, em que reclama a ação das autoridades deste país contra a a tuação dos counanienses na Espanha, se pode ler também o seguinte: "Consta-me que o sobredito calheiro de indústria Brezet expellido successivamente de Pariz e de Londres, acaba de vir instalar-se e prosseguir em Barcelona suas ardilosas tentativas de enganar aos incautos, como improvisado chefe do fantástico Estado Libre do Counani, em território brazileiro." (Archivo del Ministerio de Asuntos Exteriores - Madrid. Sección Histórica-Política - Legajo 2331). Daqui em diante, como toda a documentação utilizada neste artigo pertence ao mesmo legajo do Arquivo citado, indicarei somente sua sigla - AMAE - para identificar a procedência dos documentos. 


\section{${ }^{7}$ Valencia, F. Sempere y Compañia Editores, s/d.}

${ }^{8} \mathrm{Em}$ ofício de Araújo Beltrão aọ Ministro de Estado espanhol, de 24 de janeiro de 1950 , consta o que segue: "Com referencia ao assumpto que nos occupamos na Conferencia diplomática Semanal de 9 do corrente, em que tratei de prevenir esse Ministério acerca das manobras do imbusteiro Adolfo Brezet e seus associados..." (AMAE)

9 AMAE. Madrid, 10 de fevereiro de 1905.

${ }^{10}$ Carlos Casero foi um ativo Revolucionário Republicano. Em setembro de 1886 participou de um levantamento chefiado por Villacampa. Nesta oportunidade não obteve grande êxito, pois o movimento republicano foi dominado facilmente pelas autoridades espanholas. Sua participação em revoluçōes de caráter republicano na Espanha já demonstra sua disposição de atuar em empreendimentos ousados. Cabe recordar aqui que as revoluções republicanas da década de oitenta naquele país resultaram em um rotundo fracasso. A monarquia restaurada em 1875 gozava de uma ampla aceitação, com o que os movimentos republicanos foram considerados uma verdadeira aventura.

${ }^{11}$ AMAE. Petrópolis, 27 de abril de 1905. O telegrama a que se refere Aranguren na correspondência que acabo de citar diz o seguinte: "Ministro Negocios Extranjeros agradeceria V.E. Consejo de Estado informe acerca revolucionario español Casero quien segun denuncia prepara invasión filibustera Norte Brasil en apoyo pretendida república Cunani contratando gente en España y Francia y [palavra ilegível] desbaratar criminal empresa. Aranguren.

${ }^{12}$ Refiro-me aos ofícios de 24 de janeiro e 10 de fevereiro enviados ao Ministro de Estado espanhol, já citados anteriormente.

${ }^{13}$ Beltrão chega ao detalhe de indicar o endereço onde, em Madri, eram feitas as referidas reuniōes: "Rua Marquez de Santa Ana, n? 16, piso baixo, đireita." Esclarecia ainda que neste mesmo endereço, de 16 às 18 horas processava-se o engajamento de pessoas que estivessem dispostas a participar do exército que se organizava para defender o Counani.

${ }^{14}$ Até que se in đique o contrário, as referências que seguem são do artigo "iMinistro ó Conspirador? - La Legación de una República", do Heraldo de Madrid de 7 de maio de 1905. No dia seguinte -8 de maio - foi publicado outro artigo com este mesmo títu10.

15 As transcriçōes de o El Liberal são do artigo "Lo del Estado de Cunani - Declara el Sr. Sarrión", da edição de 7 de maio de 1905.

16 Heraldo de Madrid "tMinistro ó Conspirador?- La Legación de una República", Madri, 8 de maio de 1904 , até que se indique o con trário.

17 Outro jornal madrileno - El Imparcial -, em 8 de maio de 1905, também publica, sob o título "El Counani", algumas declarações obtidas de Sarrión, bem como o conteúdo de alguns documentos apresentados por ele à imprensa. Entre estes documentos destaca-se o chamado Libro Rojo n? 2, editado pelo governo do Counani, em 1904. Trata-se, conforme ainda esclarece El Imparcial, de um "Memorandum dirigido a las potencias con motivo del reconocimiento oficial del Estado Libre". Tal livro incluía os seguintes capítulos: Esta do Libre del Counani - su pasado, su presente y sus aspiraciones; Dados Geográficos; Administración; Constitución del Estado Libre, promulgada en 1 \% de febrero de 1901; Organización de la Alta Cámara y del Gran Consejo; Protesta dirigida á las potencias con motivo del envio de una comisión franco-brasileña al territorio nacional; Proclama dirigida por el jefe del Gobierno á la nación counaniana con 
ocasión de la retirada pacífica de los servicios y de las tropas brasileñas; Carta del Ministro de Negocios Extranjeros de Bélgica; Adhesión á la Unión postal universal; Inteligencias del Estado con colonias inglesas; Decretos sobre extranjeros y naturalización; Documentos comerciales y sobre el patrón oro; Estudios de Condreau y otros geógrafos y exploradores célebres relativos al Counani. Ao contrário do Heraldo de Madrid, El Imparcial não faz nenhum comentário sobre o que publica, reduzindo-se a justificar suas notícias sobre o Counani pelo "interés despertado en la opinión por el descubrimiento del supuesto complot contra el Brasil."

${ }^{18}$ CASERO, Carlos. Op. cit., p. 211.

${ }^{19}$ Cf., CASERO, Carlos. Op. cit., p. 214.

${ }^{20}$ Sobre este particular afirma Casero em seu livro: "Este fué el primer cañonazo de alarma. Empecé á ver realizadas nuestras sospechas, y desde aquel instante me propuse no abandonar ya aquel centro de operaciones sin dejar antes terminada mi comisión. Redoblé los celos de investigación en todos los actos que creía de alguna importancia, revistiéndome de paciencia, serenidad y resignación, esperando tranquilo nuevas y grandes sorpresas." (p.217)

${ }^{21}$ CASERO, Carlos. Op. cit., pp. 226-227.

${ }^{22}$ Ibiden., op. cit., p. 228.

23 "La Presidenta" era o nome pelo qual Casero chamava a companheira de Brezet.

${ }^{24}$ CASERO, Carlos. Op. cit., p. 233.

25 Ibiden., op. cit., p.236.

26 Ibiden., op. cit., p. 239.

${ }^{27}$ Ê o que conta Casero no final de sua obra nos seguintes termos: "A los pocos días de llegar yo a Madrid me encontré con que un juzgado de esta cor te me requería para que compareciera; compareci y se me notificó que quedaba procesado por cunanista. IEs lo único que me faltaba! Y aquí, lector, hago punto final, esperando el fallo de los tribunales, por fortuna hoy satisfactorio, absuelto. (p.242)

${ }^{28}$ Ver ofício de Araújo Beltrão ao Ministro de Estado espanhol de 10 de fevereiro e 4 de maio de 1905. (AMAE)

${ }^{29}$ AMAE - Madrid, 29 de maio de 1905.

${ }^{30}$ Ver Apêndice Documental, no 1.

${ }^{31}$ Esta "Protesta", com seus respectivos documentos, encontra-se também no AMAE, no Legajo já indicado.

32 AMAE - Segundo de Sarrión Díaz de Herrera ao Ministro de Estado espanhol, Madrid, 19, de maio de 1905 . Seguiremos nos referindo a este documento até que se indique o contrário.

${ }^{33}$ A narração que faz Casero, em seu livro de Memórias, da chega da de Sarrión a Londres, merece ser transcrita. Além de extremamente cômica revela, mais uma vez, os desentendimentos múutuos que havia entre os dirigentes do Counani. “...Sarrión empezó á relatarme lo sucedido en la seguiente forma: que había tenido que salir huyendo de Madrid; que le perseguia la policia espanhola, y que antes de dejarse prender preferia la emigración; que llegaba sin equipaje ni más ropa que la puesta, porque le habían robado la maleta en el camino, y lo que era peor, sin un céntimo en el bolsillo, puestô que su capital, que se componía de setecientas pesetas y pico, le había desaparecido 
em compañía de la maleta. A los pocos momentos llegó el presidente á la oficina, y al serle presenta do por mi el señor Sarrión, empezaron las explicaciones de una e otra parte acerca de lo sucedido. En seguida se puso un telegrama á Paris al Ministro de Negocios Extranjeros, dándole conocimiento de lo que ocurría y reclamando su presencia en Londres. Se le pagó al señor Sarrión la fonda donde se había hospedado la noche anterior, y desde luego quedó instala do en lo que por mi fué titulado Casa Cuartel, formando parte con nosotros de lo que muy bien se podía nombrar compañía de timadores ó aventureros desgraciados. La llegada del señor Sarrión fué muy comentada, demostrando bien á las claras el señor presidente su disgusto por aquella visita tan inesperada, y desde luego nadie le dió gran importancia á las exageraciones referidas por el citado señor, como así tampoco se le dió crédito al robo del equipaje y dinero. Es decir, que en los primeros momentos se ganó la antipatia de aquellas gentes, y desde luego pudo decir que su entrada en Londres fué con mala pata." (pp.223-224)

${ }^{34}$ CASERO, Carlos. Op. cit., p. 236.

${ }^{35}$ Ver Apêndice Documental, no 2.

${ }^{36}$ Este artigo do Heraldo de Madrid, assinado por José Jerique, está reproduzido em uma publicação feita no Brasil, em 1905, pela Imprensa Nacional, em forma de folheto, sob o título $A$ Farça de Cunany. A Imprensa Nacional insere no texto de Jerique, ao pé de página, alguns esclarecimentos sobre a situação do Counani, elucidando aos leitores que o território, atribuído ao mesmo, pertencia oficialmente ao Brasil desde 1900. Fornece ainda alguns dados sobre as condições de vida nesta região. Sobre Brezet escreve o que segue: "Adolpho Brezet não tem partidários e nem sequer é conhecido ou mantém agentes naquele território [entre os rios Araguari e Oiapoque]. Mesmo antes da senteça arbitral, toda a população era dedica da ao Brasil, como reconheceu o comandante Peroz, chefe da guarnição da Guyana Franceza, no seguinte trecho do seu Relatório, datado de Cayenna, 27 de maio de 1895: - 'Les hiut ou dix mille habitants fixes actuellement sur les Contesté sont Brèsiliens de coeur et patriotes dans l'ame.' No folheto da Imprensa Nacional se pode ler ainda: "Os dois Livres Rouges, n' 1 e n? 2 que Brezet fez imprimir em Pariz, - dando-os como impressos em Cunany, onde não ha typographia, - e as declarações que tem feito a jornalistas europeus são um técido de impudentes falsidades. No Livre Rouge $n$ ? 1 atrave-se a dizer que era oficial do exército brasileiro e addido militar á Legação do Brasil em Pariz, quando foi eleito chefe do imaginário Esta do de Cunani." (p.4)

${ }^{37}$ Heraldo de Madrid. "E1 19 de septiembre - Efemerides Revolucionarias", Madrid, 30 de setembro de 1905.

*Pontifícia Universidade Católica do Rio Grande do Sul

Departamento de História

90.620 Porto Alegre - RS 
64

Estudos Ibero-Americanos, XII(1) - 86

DOCUMENTO No 1

ETAT LIBRE DU COUNANI

LIBERTÉ-JUSTICE

$$
\text { conseil diétat }
$$

ERTO DE ER secrive

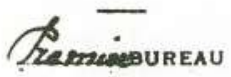

Na. $\overline{177}$

Gocelentisimo Merioc:

Gl Cotudo Pubre de Sumani.

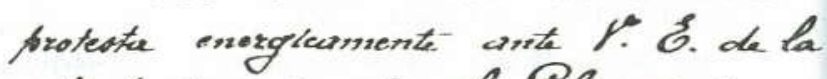

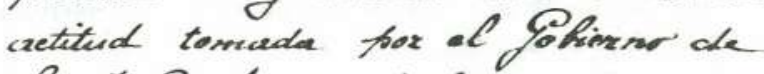
C. Clle. $P$. frente al libre forcicis de

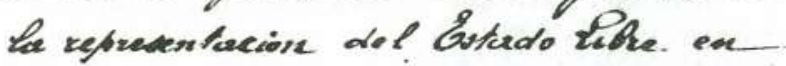
Españar.

rislog

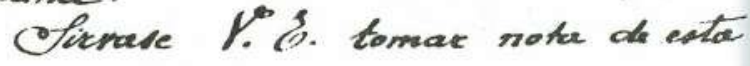

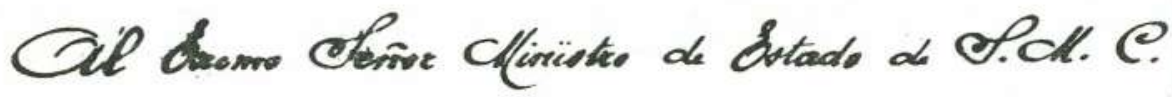


Esta do Livre do Counani: uma Questão Diplomática...

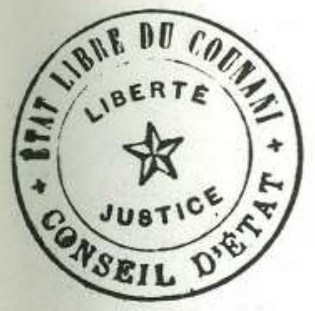

fonterta á, tà que for el momento el

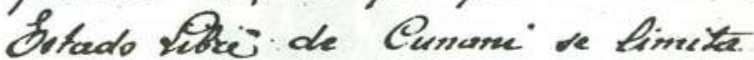
poniendo á ralro etus derechos de. dofercaroice.

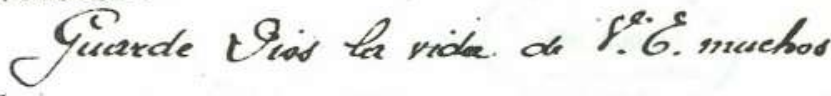 añor.

if Envilfer d. blat

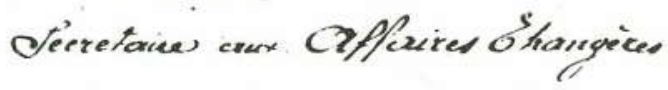

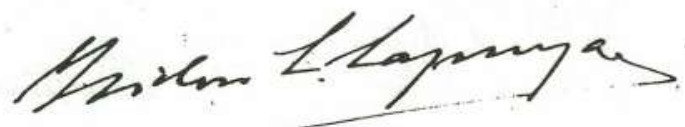

Pondres en M(Nivion, gol Othayo 1905 
66

Estudos Ibero-Americanos, XII(1) - 86

DOCUMENTO No 2

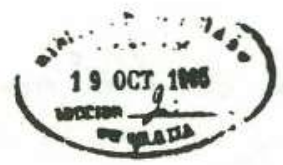

$$
\text { E. 117 }
$$

$\operatorname{Ving} / 4$

Gancedence.

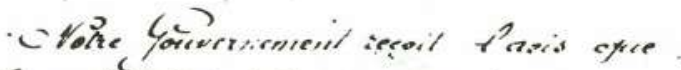

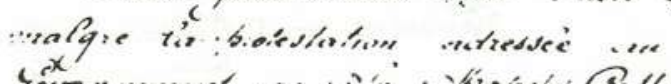

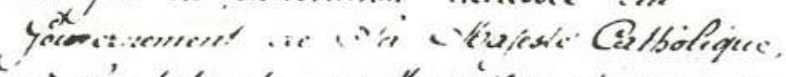

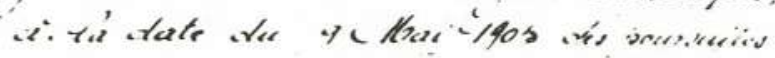

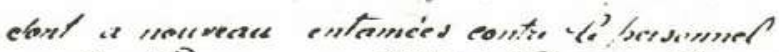

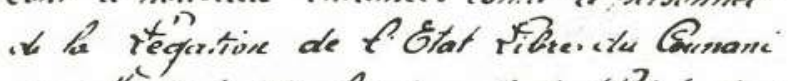

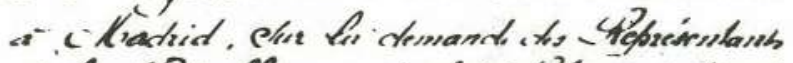

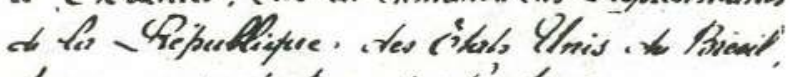

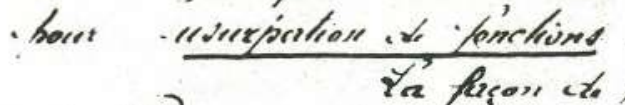

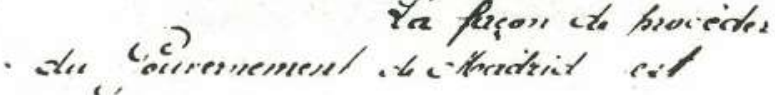

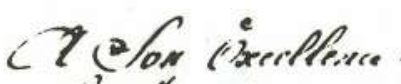

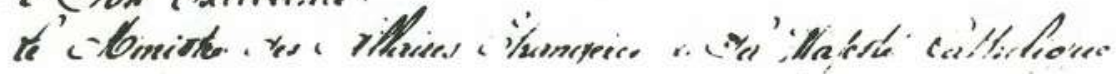




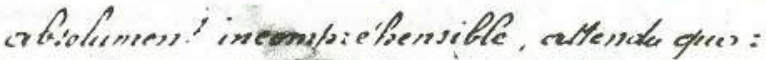

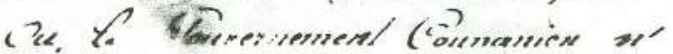

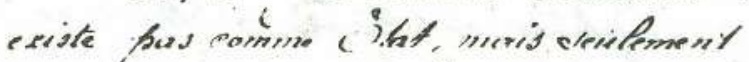

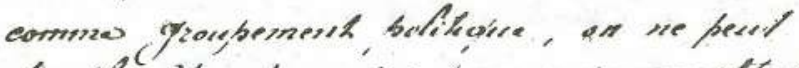

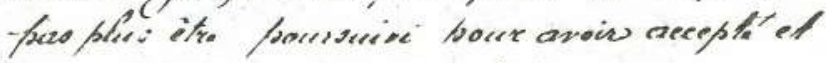

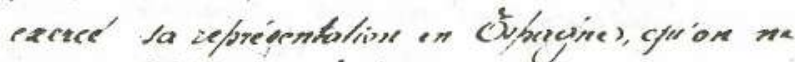

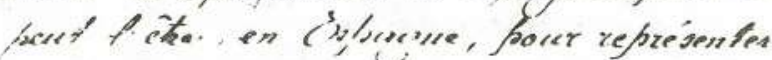

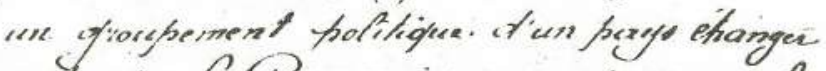

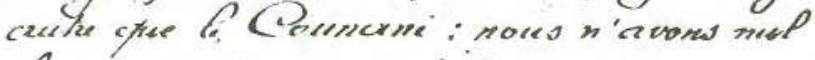

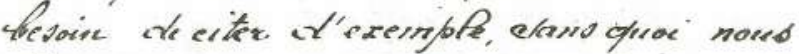

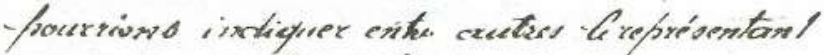

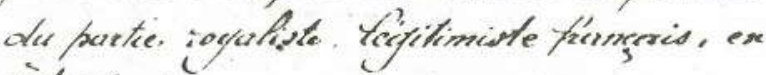
ojfarcyur ;

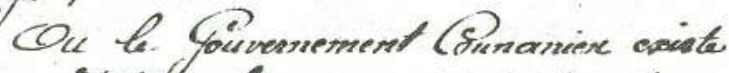
comma Etat, shan, ceux qui Le divent tes

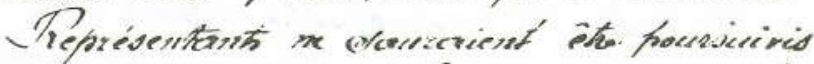
pour usurpative de fonctiones cyue efese fa

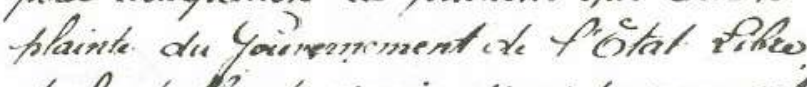

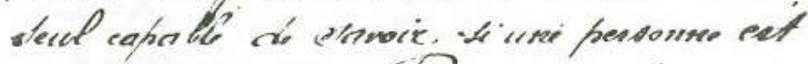
ose nest pas won. Prepréseritant.

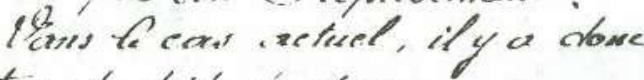
riolutive du choil ates qeers:

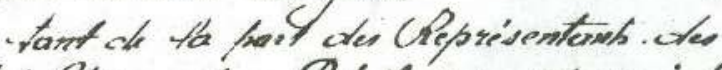

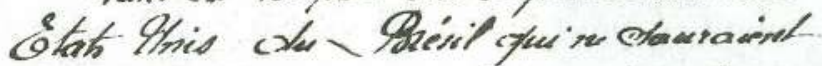
its. admis is isofis fudieriaikement

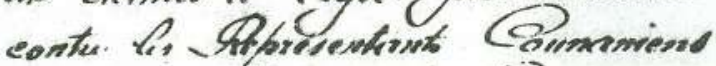

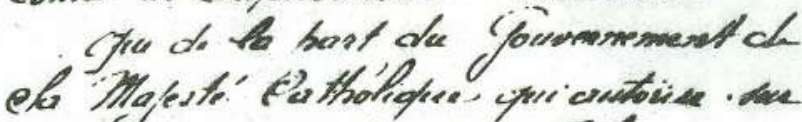

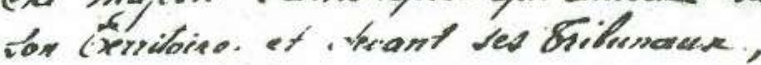


68

Estudos Ibero-Americanos, XII(1) - 86

un arte qui constitue. celle vidations.

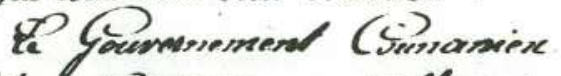

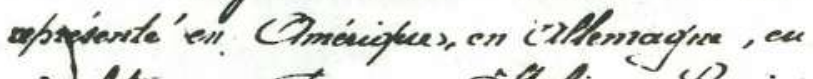

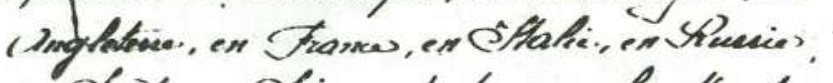

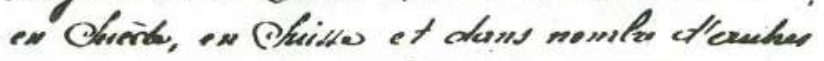

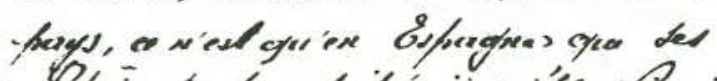

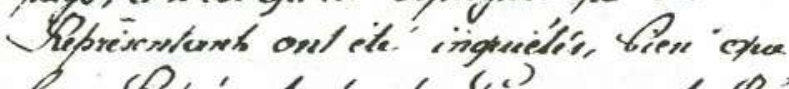

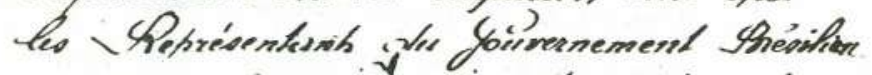

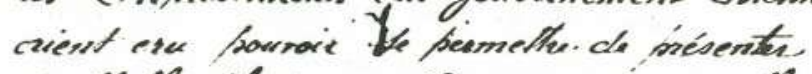

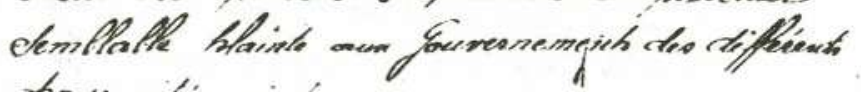
thaype estes erivesued.

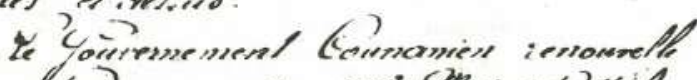

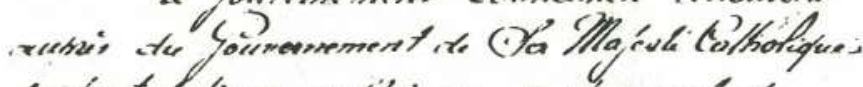

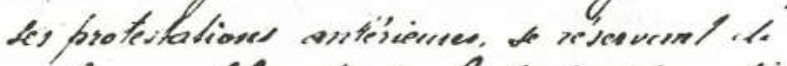
seifarmes yluss band - Aa fuste vitureation

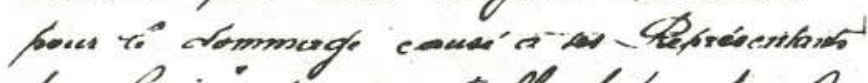

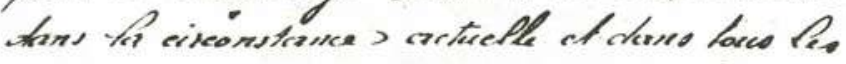

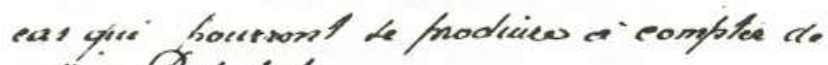
eethe ( Rotwototuse.

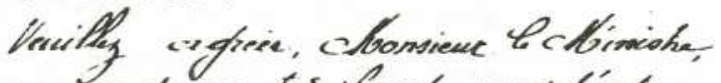

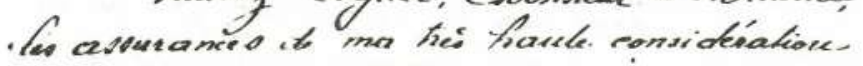

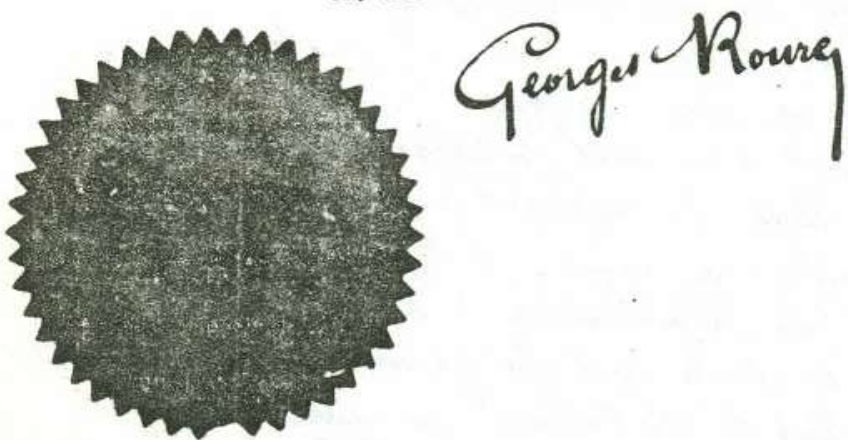

Cuncilen d Etat Senctaina ginesal du Gounernement

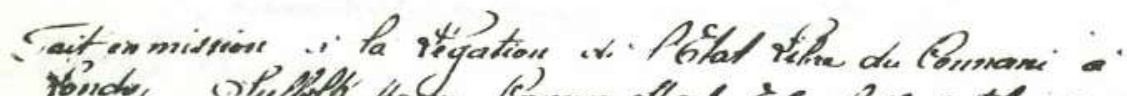

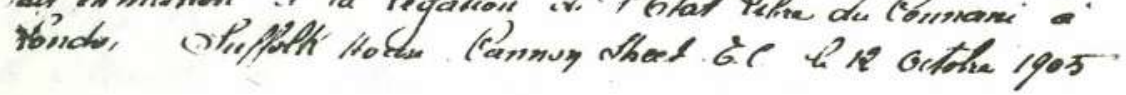

